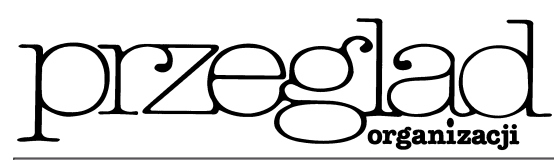

\title{
System HACCP \\ w przedsiębiorstwie
}

https://doi.org/10.33141/po.2005.12.09

\section{Anita Fajczak-Kowalska}

Wstęp

I ntegracja Polski z Unia Europejska wymagała od producentów artykułów żywnościowych wprowadzenia do produkcji systemu bezpieczeństwa żywności HACCP (Hazard Analysis and Critical Control Points).

W Unii Europejskiej obowiązek stosowania HACCP przez producentów żywności wynika z dyrektywy o higienie żywności (93/43/EEC), jak również z dyrektyw sektorowych dotyczących różnych produktów pochodzenia zwierzęcego.

Dyrektywa 93/43/EEC z 14 czerwca 1993 roku jest dyrektywą obowiązkowa dla wszystkich krajów członkowskich Unii Europejskiej. Oprócz obowiązku stosowania w produkcji zasad HACCP określa również wymogi dotyczące higieny, zakupów, dystrybucji i sprzedaży żywności.

Podstawowe postanowienia dyrektywy 93/43/EEC odnoszace się do higieny żywności:

- dyrektywa dotyczy wszystkich krajów członkowskich UE;

- zakłada, że najważniejszą sprawą jest ochrona zdrowia ludzkiego;

- chroni konsumentów przed skutkami spożywania artykułów żywnościowych niezdatnych do spożycia i niebezpiecznych;

- zakłada wprowadzenie standardów i nadzoru higieny żywności przez wszystkie etapy jej produkcji; - przedstawia ogólne zasady i procedury higieny dla żywności.

Przepisy dyrektywy 93/43/EEC nie nakazują krajom członkowskim ścisłego dostosowania się do nich. Kraje mogą utrzymywać i poprawiać oraz wprowadzać swoje przepisy dotyczace higieny pod warunkiem, że wymagania nie będą mniejsze i nie będą stanowić przeszkody w handlu żywnością z innymi krajami ${ }^{1}$.

\section{Charakterystyka systemu HACCP}

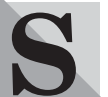

krót HACCP pochodzi od określenia w języku angielskim, które tłumaczy się jako Analiza Zagrożeń i Krytyczne Punkty Kontroli (system zapewnienia bezpieczeństwa zdrowotnego żywności). System HACCP jest rekomendowany przez Swiatową Organizację Zdrowia (WHO), Codex Alimentarius oraz wymagany ustawodawstwem Unii Europejskiej.

System ten powstał w latach 60 . ub. wieku w USA, kiedy to firma Pillsbury Company opracowała na zlecenie NASA (National Aeronautics and Space Association) i US ANL (US Army Nautic Laboratories) program stworzenia systemowych gwarancji uzyskania żywności bezpiecznej zdrowotnie dla astronautów.

Według Codex Alimentarius [1997] HACCP stanowi system, który identyfikuje, ocenia i kontroluje ( $\mathrm{w}$ sensie nadzorowania/panowania) zagrożenia istotne dla bezpieczeństwa zdrowotnego żywności.

Przed wprowadzeniem w przedsiębiorstwie systemu HACCP należy wdrożyć zasady Dobrej Praktyki
Przegląd Organizacji, Nr 12 (791), 2005, ss. 36-37 www.przegladorganizacji.pl Towarzystwo Naukowe Organizacji i Kierownictwa (TNOiK)

Produkcyjnej (GMP - Good Manufacturing Practice) oraz zasady Dobrej Praktyki Higienicznej (GHP - Good Hygiene Practice), których celem jest stworzenie odpowiednich warunków do wytwarzania żywności bezpiecznej pod względem higienicznym.

System ten polega na organizacji działania w przedsiębiorstwie, które ma służýc do zapewnienia bezpieczeństwa zdrowotnego żywności podczas jej produkcji i dystrybucji, identyfikacji występujacych zagrożeń (biologicznych, chemicznych, fizycznych) oraz określenia metod ich uniknięcia. Ma on charakter prewencyjny, przenosi ciężar kontroli z końcowego produktu na poszczególne fazy całego procesu produkcji i dystrybucji, wymaga udziału całego personelu zakładu2).

System HACCP charakteryzuje się tym, że jest to: - logiczny, profesjonalny system zapewnienia jakości żywności: • identyfikuje zagrożenia (biologiczne, chemiczne, fizyczne); • ustala działania zapobiegawcze; - szacuje ryzyko; • wskazuje krytyczne punkty kontroli Critical Control Points (CCP); • nadzoruje CCP metodą monitorowania;

- system nadzorowania procesu produkcyjnego i samokontroli przedsiebiorstwa: • dokumentuje przebieg procesu produkcyjnego; $\bullet$ tworzy pełną dokumentacje procesu produkcyjnego;

- system samoregulujący się: $\bullet$ sprawdza efektywność własnego funkcjonowania; $\bullet$ poddaje się weryfikacji;

- system sprawnie działający - może podlegać certyfikacji ${ }^{3)}$.

Zarówno projektowanie, jak i wdrażanie systemu HACCP do praktyki polega na realizacji sekwencji działań nazywanych zasadami systemu. Jest to formuła siedmiu zasad systemu HACCP, do których zaliczamy: zasade 1. - przeprowadzenie analizy zagrożeń (identyfikacja wszystkich możliwych zagrożen, przeprowadzenie analizy zagrożeń i wskazanie działań zaradczych); zasade 2. - określenie krytycznych punktów kontroli (CCP); zasadę 3. - ustalenie wartości krytycznych (ustalenie wartości docelowych wraz z tolerancjami oraz wartości krytycznych w CCP); zasadę 4. - opracowanie systemu monitorowania CCP; zasade 5. - ustalenie działań korygujących; zasade 6. - ustalenie procedur weryfikacyjnych; zasadę 7. - opracowanie i prowadzenie dokumentacji.

Przed wprowadzeniem siedmiu zasad HACCP potrzebny jest wstęp do projektowania systemu, który rozpoczyna się od powołania zespołu roboczego ds. HACCP. Kolejne etapy to: stworzenie opisu produktu, określenie przeznaczenia konsumenckiego produktu, utworzenie diagramu przepływowego oraz schematu procesu technologicznego, sprawdzenie przebiegu procesu technologicznego na linii produkcyjnej.

Realizacja zasad systemu HACCP służy do eliminowania lub ograniczania do akceptowalnego poziomu ryzyka wystąpienia w przetworzonej żywności zanieczyszczeń chemicznych, fizycznych oraz mikrobiologicznych. Dotyczy to zarówno tych zanieczyszczeń, które mogły obciążý surowce, jak i tych, które pochodziły z procesu przetwórczego. 
Wszystkie osoby będące w zespole HACCP muszą być odpowiednio przeszkolone i musza posiadać dokument stwierdzający zdany egzamin. Całym zespołem kieruje kompetentny pełnomocnik, który jest jednocześnie kierownikiem zespołu.

Projekt systemu HACCP musi być tworzony indywidualnie, w dostosowaniu do specyfiki i warunków produkcji każdego przedsiębiorstwa oddzielnie, ponieważ każde przedsiębiorstwo ma różne elementy procesu produkcyjnego i wynikające z tego różne zagrożenia.

Każde przedsiębiorstwo (firma) ubiegająca się o certyfikat HACCP musi posiadać procedury, instrukcje i dokumenty, w których określone są wszystkie procesy krytyczne odnośnie do bezpieczeństwa, legalności i jakości produktu.

Organizacja zobowiązana jest do posiadania pełnego opisu produktu w zakresie bezpieczeństwa żywności z uwzględnieniem procedur weryfikacji w celu sprawdzenia skuteczności działania systemu.

Według J.B. Berdowskiego ${ }^{4)}$ „wszystkie systemy zwiazane z bezpieczeństwem żywności - HACCP, BRC, IFS (International Food Standard - Międzynarodowy Standard Żywności) biora pod uwage ryzyko, które oznacza niebezpieczeństwo zaistnienia negatywnych skutków dla zdrowia oraz dotkliwość takich skutków w następstwie zagrożenia". Ocena ryzyka oznacza proces wsparty naukowymi badaniami składajacy się z czterech etapów. Etap pierwszy, to identyfikacja zagrożenia, etap drugi - charakterystyka niebezpieczeństwa, etap trzeci - ocena ekspozycji i etap czwarty - charakterystyka ryzyka.

Po wprowadzeniu systemu HACCP, ryzyko przedsiębiorstwa jest bardziej widoczne, co wpływa na szybszą reakcję i umożliwia podjęcie odpowiednich niezbęnych kroków zapobiegawczych. W obecnych czasach jakość i bezpieczeństwo zdrowotne produktów żywnościowych dla konsumenta odgrywa bardzo ważna role, zwiększa jego zaufanie do wyrobu. Wiaże sie to z redukcją kosztów wynikających z wadliwości produktów. Oznacza na przykład zmniejszenie liczby kontroli jakości produktów końcowych, eliminacje ewentualnej kwarantanny produktów finalnych, uniknięcie strat z tytułu powstających odpadów, eliminację braków oraz zmniejszenie liczby reklamacji i skarg.

\section{Specyfika branżowa HACCP}

\section{Owoce i warzywa oraz przetwórstwo}

Każdy owoc i warzywo, chociaż mają wiele cech wspólnych, należy traktować oddzielnie. Wynika to z tego, że owoce i warzywa posiadają inny skład chemiczny oraz właściwości fizyczne, co wymaga indywidualnych zabiegów podczas hodowli i zbiorów, odmiennych warunków chłodniczych i przechowywania. Wszystkie te cechy muszą być brane pod uwagę przy rozważaniu potencjalnych zagrożeń mikrobiologicznych oraz przy ich kontroli.

\section{Produkcja mięsa oraz przetworów mięsnych}

Zwierzęta rzeźne stanowia dobre źródło dla drobnoustrojów, które są odpowiedzialne za wywoływanie u ludzi chorób zakaźnych pochodzenia odzwierzecego. Mimo ciągłego postępu medycyny i weterynarii oraz znacznej poprawy w warunkach sanitarnych hodowli zwierząt, nie udało się wyeliminować chorób infekcyjnych, które sa przenoszone w sposób naturalny ze zwierzat na człowieka.

Przemysł mięsny musi doskonalić jakość zdrowotna, między innymi poprzez podnoszenie trwałości produk- tów. W tym celu tworzone sa nowe technologie produkcji, które uwzględniaja bezpieczne dodatki i nowe metody utrwalania wyrobów. Producenci mięsa i wyrobów mięsnych zobowiązani sa do oceny ryzyka występowania zagrożeń w procesach produkcyjnych.

\section{Produkty specjalnego żywieniowego \\ przeznaczenia oraz preparaty odżywcze}

Zaliczamy do nich: dietetyczne środki spożywcze, odżywki, środki spożywcze specjalnego przeznaczenia żywieniowego oraz grupy środków specjalnego żywieniowego przeznaczenia np. preparaty dla niemowlat, środki spożywcze stosowane w dietach, środki spożywcze bezglutenowe. Zapewnienie bezpieczeństwa żywności - w celu ochrony zdrowia konsumenta - to główne zadanie producentów żywności i nieodzowny warunek ich działań. Producent odpowiada za szkody, które wyniknęły z powodu wad produktu, jak również nie może uniknąć odpowiedzialności za wadliwy wyrób.

\section{Mleko i przetwory mleczarskie}

W produkcji mleka i przetworów mlecznych występuje kilka rodzajów zagrożeń. Są to między innymi: zagrożenia mikrobiologiczne (zagrożenie żywności rozwojem pleśni, wirusów, bakterii), zagrożenia chemiczne (związki metali ciężkich, pestycydy, azotany i azotyny, antybiotyki i inne leki, środki sanityzacyjne, zanieczyszczenia techniczne i czynnik ludzki) i zagrożenia fizyczne (zanieczyszczenia mechaniczne dostające się podczas pozyskiwania surowca, zanieczyszczenia przedostajace sie do żywności w trakcie produkcji, ciała obce wprowadzone świadomie lub nieświadomie poprzez konsumenta).

\section{Podsumowanie}

T ak wynika z przeprowadzonych badań, przedsiębiorstwa, które wdrożyły system HACCP obserwuja zmniejszenie kosztów wadliwości wytwarzanych wyrobów oraz zwiększenie komunikacji merytorycznej między dostawcami i odbiorcami. Wytwarzany produkt staje się bardziej konkurencyjny na rynku, gdyż jest bardziej bezpieczny pod względem zdrowotnym i lepszy jakościowo. Wdrażanie zasad GMP/GHP może w niektórych przedsiębiorstwach wiązać się ze zwiększeniem kosztów, np. na przebudowę pomieszczeń, wymianę wyposażenia zakładu. W firmie, która funkcjonuje w pełnej zgodności z zasadami GMP/ GHP, wdrażanie systemu HACCP nie powinno powodować nadmiernych kosztów. Koszty, które mogą wystąpić, będą związane ze szkoleniem pracowników lub zakupem urządzeń służacych do pomiaru czy kontroli.

Analiza Zagrożeń i Krytyczne Punkty Kontroli na początku dotyczyła jedynie zagrożeń o charakterze mikrobiologicznym. Obecnie, po rozwinięciu systemu, wdrażajac HACCP do przedsiębiorstwa bierze się pod uwagę zarówno zagrożenia mikrobiologiczne, jak i chemiczne i fizyczne.

dr Anita Fajczak-Kowalska Instytut Ekonomik Stosowanych Uniwersytet Łódzki

\section{PRZYPISY}

1) A. FAJCZAK-KOWALSKA, Wymagania dotyczace jakości żywności wynikajace $z$ dyrektyw Unii Europejskiej, „Problemy Jakości" 4/2004, s. 6-9.

2) A. HUTYRA, EIC Gdańsk, poczta@euroinfo.gda.pl

3) HACCP $i$ higiena żywności, Wydawnictwo Forum.

4) J.B. BERDOWSKI, Wptyw wspótczesnych systemów zarzadzania jakościa, a szczególnie HACCP, BRC, IFS na proces doskonalenia organizacji zajmujacej sie produkcja i obrotem żywnościa, „Problemy Jakości” 9/2005, s. 9-13. 